\title{
Societal Acceptance of Crime \& Rape: Blaming Victims and Excusing the Behavior of the Offender
}

\author{
Scott A Johnson* \\ MA, LP, DABPS Forensic Consultation, USA \\ Submission: November 12, 2016; Published: January 04, 2017 \\ *Corresponding author: Scott A Johnson, MA, LP, DABPS Forensic Consultation, USA, Tel: (612) 269-3628; \\ Email: scott@forensicconsultation.org; www.forensicconsultation.org
}

\begin{abstract}
This article is my professional opinion in response to the major cases of rape and alleged police misconduct against criminals. As a forensic psychologist of over 28 years, educator and researcher, and a respected author, I have had enough. Societal ignorance has gotten out-of-control! We, as a society, appear to be lowering the threshold of accountability. We hold some offenders less accountable for their actions than others, despite the same crimes being committed. And what is this lower accountability based on: often ignorance, wealth, and race, rather than on facts. I will speak to the issues of objectification of women, rape, and the role of alcohol in violent crimes. I will also address the issue of respecting law enforcement and holding criminals accountable for their own behavior rather than blaming those who have to respond to the criminal's behavior. One important fact to remember is that sociopaths (environmentally created psychopath) and psychopaths (biologically created) lack conscience and care little if any for the safety or rights of others. Despite this, however, they still know right from wrong- they simply do not care!
\end{abstract}

\section{Introduction}

Do criminals, including sex offenders, know that what they are doing is wrong?

The answer is simple - absolutely the criminal and sexual offenders are well aware that their behavior is wrong. We think before we act, every time. To engage in consensual sex, we compromise, respect our partner, and enjoy the intimacy that sex can offer. To rape (including having sex with an unconscious or debilitated victim), we have to first believe that we have the right to take sex, and to believe that the victim deserves to be raped. Rape has nothing to do with intimacy or respect, but violence.

\section{Double standards and misogyny}

Think about the double standard society places on women. If a woman has more than one sex partner, we call her a whore or slut. If a man has more than one sexual partner, we call him a stud. This double standard may help some to condone the abuse and mistreatment of women though it does not cause the abuse to occur. How is it possible that the same behavior has different values because of whether someone is male or female? Men use the terms bitch, whore and slut to justify abuse and rape. Yet somehow these very same men become offended when someone uses these same terms against them or their family members, especially when used against their wives, sisters, or mothers. Really, have we come to justify abuse and rape so openly? Unfortunately we have.

\section{What about respecting law enforcement?}

We have come to a deadly serious situation in which some have come to view police as enemies and adversaries. We hear people speaking of holding police officers accountable for the injuries and/or deaths that occur at the hands of police, despite the fact that the majority of such situations involved justified use of force. Somehow people conveniently forget that everyone has the power to make decisions about what they do and what they choose not to do, that no one can force or make a person commit an act of violence or an act of benevolence. I have heard so many violent offenders complain about the police, the courts, and mental health professionals holding them accountable for their chosen actions. It is as though somehow the criminal should be given a free pass to be excused from any culpability of their actions. In short, the violent offender who assaults or kills a police officer is simply nothing more than a thug, a criminal who made a decision to engage in illegal and violent behavior.

The criminal or thug justifies their actions with mistruths and rationalization and projection of blame onto everyone except themselves. Conversely, the police officers' behavior also did not significantly influence the violent offender's decision to attack violently or resist the officer. Only the individual decides whether to respect and listen to police or to resist. Non-criminals choose to listen to police officers even if being wrongfully arrested. Law 
abiding citizens realize that if they are wrongly arrested they can bring legal action against the police department for the unlawful arrest. However, resisting arrest, even if the arrest was unlawful, is still resisting (which is a crime) and the offender should still be held fully accountable for their choice to resist the officer. See Hassell \& Archbold [1] for more on offender/officer interaction.

\section{Family factors impact on violent behavior}

The violent offender most often comes from a violent environment, which may involve family members and friends who support and condone the offender's behavior. Permissive parenting involves either treating your child as an adult friend and rarely if ever disciplining them or on the other extreme providing physically and financially for your child but failing to establish any sense of relationship or attachment. Either type of permissive parenting can hinder or prevent a child from developing appropriate degrees of morality. Social learning theory lends support for this premise. The criminogenic or criminal based family and support system justifies violent and illegal behavior by either engaging in illegal behavior themselves or by aiding and abetting the family member's/friend's criminal conduct by failing to hold them accountable and by defending and justifying the criminal's behavior. When this occurs, the family and friends help support the offender's deviant and violent thinking. Often the community and at times even the Courts play into this aiding and abetting criminal thinking and criminal behavior by giving weak and laughable sentences to those who instead required and deserved more severe punishments.

\section{Cases in the media}

One current example of this is Michael Brown, who was shot and killed by a police officer in August 2014 [2] after having committed a strong-armed robbery, assaulting a police officer, and charging at and refusing to follow the officer's commands. Michael Brown's mother and step-father are prime examples of aiding and abetting Michael's criminal and violent behavior. The Department of Justice (DOJ) as well a grand jury determined that the use of force by police was justified against Michael Brown including the use of deadly force. This was based on facts which supported that Michael's violent conduct warranted the officer's use of deadly force. Yet Michael's mother and step-father strongly defend Michael's behavior (e.g., strong armed robbery, assault on a police officer, refusing to follow the commands of a police officer) and portrayed him as an innocent, nonviolent baby boy (the picture they used for their protest was Michael as an infant or young child- however he was actually 18 when he committed his final violent behavior!).

His mother and step-father failed to hold Michael accountable for this violent criminal behavior, instead blaming the police officer for wrongly stopping and killing their son. Simple though- had Michael followed the commands of the officer and surrendered, he would have been arrested instead of killed. How ironic, his own choice took his life. Another example is the Affluenza case in Texas where a 16 year-old Ethan
Couch drove while intoxicated and caused a car accident that resulted in the death of 4 people and injuring several others [3]. Couch's attorney successfully argued that his parents were too permissive and failed at their job to instill a sense of morality in Ethan because they did not hold him accountable for his actions. The Couches are financially wealthy. Ethan was given no jail or prison time, but rather probation and substance abuse treatment. Of course, Ethan and his mother Fled to Mexico and were subsequently arrested. While in Mexico, he was partying, drinking, and of course, breaking probation.

One important fact about psychopaths and sociopaths is that they know right from wrong, they just simply do not care. So even without having a sense of morality the criminal, like Michael Brown and Ethan Couch know right-from-wrong and choose to hurt others and violate the rights of others. Another example, Brock Turner, the 20 year-old white male from an affluent family, referred to as the Former Stanford Swimmer. Interesting that a man from a wealthy family gets the nick name of the Former Stanford swimmer rather than just a sex offender or rapist. Somehow the media softens Mr. Turner's violent sexual behavior. He received a very minor sentence for a vicious sex crime [4]. He was sentenced to 6 months in jail and 3 years-probation and lifetime sex offender registration. He was intoxicated at the time he raped the victim and claimed that he did not believe that having sex with an unconscious woman was rape. What kind of family raises a son to believe that an unconscious woman deserves to be raped, yet that is what he stated? And then he feigned remorse and regret, fooling the Judge, Jury, and prosecutor.

Let me tell you something about genuine remorse- if you experienced remorse at the time of the crime, you would have ceased your violent and sexually assaultive behavior. However, there is no evidence that having remorse makes a person less likely to reoffend with violent or sexually violent behavior. In addition, he knew exactly what he was doing throughout the rape, otherwise how could he have raped? If he had the capacity for genuine remorse, he would have ceased his violent rape behavior. Rape involves complex behavior. Rape does not happen because someone is intoxicated, it happens because someone makes a conscious decision to force sexual contact. Another recent example is Austin James Wilkerson, a former University of Colorado student who raped a female friend who was intoxicated [5]. He told the victim and others that he would take care of her given her current intoxicated state. He took her home and proceeded to rape her. She had previously refused his sexual advances. He even went as far as to text her friend in which he posed as the victim thanking himself for caring for her, all the while raping her. His demonstration of remorse was apparently believed as a reason to give him a minor sentence: two years in jail with work/school release, 20 years sex-offender specific intensive probation, and lifetime registration as a sexual predator with the ability to have the registration removed after 20 years. 
This was a calculating, predatory sexual offense. He not only took possession/abducted his victim in the presence of others, but his roommate was home during the rape. He was cunning enough to even send the texts to the victim's friend in an attempt to make it appear she (victim) appreciated his caring for her. Again, remorse is meaningless as is has nothing to do with sexual or violent recidivism. And again, he is a calculating predatory sexual offender who likely has many other victims and will likely reoffend while on supervision. There are teachers convicted of engaging in sex with their minor students who have also received ridiculously inappropriate minor sentencing. In one case the Judge commented on how the 15-year-old female victim looked older and consented to the sexual contact. What? A minor can never give consent to engage in sex with an adult, ever! Even more disturbing, a person in a position of power and/or authority cannot engage in sex with a subordinate- that includes students even at the college level. For more, see the news report by Minor, [6]. There are numerous other examples available. Stop blaming the students for teachers engaging in conscious decisions to molest and rape.

I have even heard professionals, especially mental health (therapists, psychologists, and psychiatrists and judges) proffering their opinion that the violent offender's behavior was somehow "out of their control" despite any tangible evidence to support their opinion. In fact, regardless of whether an offender has mental illness or emotional instability, they are still $100 \%$ responsible for their actions. The only exception to this is when it can be proven that the offender was actively psychotic at the time of their violent behavior. Even the Colorado shooter was found to be "sane" at the time he committed the crime despite a long and proven history of Schizophrenia. Having AttentionDeficit/Hyperactivity Disorder, Bi-Polar Disorder, substance abuse/dependency, or antisocial personality disorder do not in my professional opinion justify violent behavior nor is the offender "out of control" or unable to cease their destructive or violent behavior. They still make choices and they count on others blaming their mental health diagnoses or their substance use for their violent behavior.

\section{What the literature has to say}

There is evidence that neurological and psychological factors may predispose an individual to behave with more violent or amoral behavior. There are some basic personality traits, and cognitive, emotional and motivational processes, which are associated with an increase in the risk of violence [7]. The risk of violence may be understood in terms of four fundamental personality dimensions, impulse control, affect regulation, threatened egotism or narcissism, and paranoid cognitive personality style [8]. Neurophysiological findings have evidenced that affective impulsivity is related to functional impairment of prefrontal cortex [9-11] and that alcohol weakens brain mechanisms that normally restrain impulsive behavior, including inappropriate aggression $[9,12,13]$. There is some evidence that human aggressive behavior may be premeditated, proactive and instrumental, or reactive and impulsive.

Impulsive aggressive behavior has also been linked to biological [14,15], psychological [16], social and contextual factors [7]. Support for the biological basis for impulsive aggressive behavior in individuals with personality disorder has been found [17-19]. In addition, a gene encoding for serotonin receptor has been found to predict impulsive aggressive outbursts while under the influence of alcohol $[20,21]$, though there is no evidence that the person is unable to control their violent behavior but rather that they are more prone to engaging in violent behavior. However, let's be clear about the limitations of all of the research related to aggression and the impact of alcohol use on aggression and rape. No published research to date has demonstrated that an individual under the influence of alcohol or an individual with certain biological and/or psychological deficits or predispositions are actually out-of-control when it comes to engaging in aggressive or sexually aggressive behavior.

These same individuals pick and choose when they act-out and in what manner they act-out. Regardless of whether they have poor coping skills and poor anger management skills or even psychopathy or sociopathy, they still know right from wrong and it comes down to the fact that they simply do not care if they hurt someone nor do they care about the consequences on others, only the consequences on themselves. In my article on understanding the role of alcohol during rape [22] I offer evidence that the impact of alcohol intoxication actually improves the intoxicated individuals' ability to continue with their chosen and focused-on behavior (myopia). This means that if the individual is focused on rape, the more they drink the more focused on rape they become. This makes it easier for some to justify physical and sexual aggression while intoxicated, however it is still a conscious choice the offender makes. There is no proof that intoxication or other psychological factors cause a person to behave in a violent manner. If a criminal chooses to assault or rape while intoxicated, they are still in $100 \%$ control of their thoughts and behavior, they simply care less while intoxicated about the moral and legal ramifications.

The intoxicated individual does demonstrate impairment in motor skills and some degree of judgement, but still has to make the final conscious decision to behave in a violent or nonviolent manner, or to get into a car to drive while impaired. In fact drunk drivers often have driven drunk many times prior to their first conviction for DWI, yet they managed to navigate their car and make it home most of the time. In addition, the majority of individuals who become intoxicated are typically peaceful and focused on having fun, not harming others. Consider how many times the rapist or assaulter became intoxicated and how few times they actually acted violent or raped while intoxicated. If alcohol or psychological/biological factors caused violent behavior, then it stands to reason that most if not every time the individual is intoxicated they would behave violently. This 
is simply not the case. Even Jeffery Dahmer, who was clearly mentally disturbed, demonstrated significant restrain in that he only had approximately 14 victims over a 13 -year crime spree. He talked about not being able to stop the intrusive and violent thoughts he experienced yet only acted-out on those thoughts once a year.

The vast majority of mentally ill individuals who are dangerous are almost exclusively dangerous to themselves, not others. In addition, I have yet to see any statistical data that those with any mental health diagnosis are actually "out-ofcontrol" with the exception of active psychosis. In short, mental health problems and substance abuse/dependence are never a justification for engaging in criminal or assaultive behavior, ever. Listening to the words used by the violent offender helps understand how they select violent behavior. Often they objectify the intended victim, making it easier to harm the victim while not necessarily viewing the victim as a person. Of course there comes the justification of blaming the victim, the offender often believing and telling the intended victim that they (the victim) made or forced the offender to act out. The bottom line is that the violent offender makes a conscious and deliberate decision to offend. No excuses or blame on anyone else, not on law enforcement, not on mental health issues, and certainly not on the victim.

The offender makes it easier to offend by strengthening their self-talk that supports acting-out. The only exception would be someone who is actively psychotic at the time they engage in the criminal or violent behavior. Remember that even the mentally ill may experience periods of improved thinking as they cycle in their mental illness (again, the Colorado shooter is a prime example). But make no mistake. Your choice of behavior (verbal, physical, or sexual) is always, yes always $100 \%$ under your control. No one can make you say or do things, only you choose how to react. Even when drunk, you know damn well what you are saying and doing and make decisions that only you can make. Alcohol does not ever make us do or say anything; alcohol does not cause us to behave without first thinking about what we want to do. For example, if you rape someone while you are intoxicated, you made a conscious, thought-out decision to rape. The alcohol may make it easier to ignore the consequences, but alcohol never causes you to do anything nor does alcohol prevent you from knowing what you are doing when you are doing it.

While drunk, you still know right from wrong and always know what you are doing at that time. I have heard claims from rapists that they were too drunk to know what they were doing. However, they were lying. They knew damn well what they were doing. Rape is a complex series of behavior, including countering the victim's resistance and avoiding detection. Providing someone with a date rape drug is a conscious and thought-out choice. It takes a lot of focus to engage in sexual activity. It takes a significant degree of dedication and commitment to counter resistance to rape. It also takes a considerable degree of self- righteousness and arrogance to believe that the victim deserved to be raped and that the offender goes about their life as though nothing happened.

Lastly, to have sex with a person who is unable to respond verbally or physically out of fear or incapacitation (e.g., drugged, passed-out) takes significant commitment and a desire to have sex knowing that the victim is not responding to the sexual behavior. Who has sex with an unresponsive person or with a person who is being physically forced or too fearful to refuse except for a rapist? Only a rapist rapes, not the alcohol, not poor judgement, not a moral lapse. The only people who rape are those who for some time believed it was alright to rape- it was never a last minute decision [23].

\section{One last issue}

Most rapists have far more victims than the number known to law enforcement. Approximately only $5 \%$ to $37 \%$ of attempted or completed rapes (physical forced sex contact) are reported to law enforcement officials [24-26]. Only approximately $10 \%$ of sexual assaults (psychologically forced sex contact) are reported. In addition, Heil, Ahlmeyer, and Simons [27] found that incarcerated and paroled sex offenders had approximately 3 to 9 times more victims than what was previously known that were revealed in/via polygraph and treatment. Some research may place those numbers higher for unknown victims. This raises concerns because most sex offenders have far more victims than known at the time they are sentenced for their first sex offense. Leniency shown by the courts may have a negative impact of condoning the offender's sex offense behavior by giving a more lenient sentence or failing to give prison time.

\section{Conclusion}

\section{What we can do?}

Leaning to respect women requires that we first believe that all women deserve respect. Second, stop using terms that objectify and degrade women. Let's have a change of acceptability for men to stop objectifying women. Lastly, understanding the role that thoughts play, hold men accountable for using derogatory terms and for objectifying women without excusing their behavior as being "something they did not mean". You mean what you say and you mean what you do, period. As for changing attitudes about law enforcement, highlight and appreciate the good that effective policing has on any community. The offender makes their own decisions and the officer has to respond to the offender's choices. Lastly, hold offenders accountable for their behavior without regard for their justification or reasoning they offer for their violent behavior. Stop sentencing wealthy or Caucasian sex offenders to less severe punishments than the crime deserves. Justice requires a blind eye to race and wealth. Years of intensive supervision and lifetime sex offender registration are appropriate consequences and punishments for sex crimes of any type. However, a prison sentence is also an important consequence for any type of violent crime. Consider 
the impact on the victim, as well on the many victims who have yet to be identified- their injury/damage may be life long, at the very least the memory is lifelong.

\section{References}

1. Kimberly D Hassell, Carol A Archbold (2010) Widening the scope on complaints of police misconduct. Policing: An International Journal of Police Strategies \& Management 33(3): 473-489.

2. (2015) Department of Justice Report Regarding the Criminal Investigation into the Shooting Death of Michael Brown by Ferguson, Missouri Police Officer Darren Wilson.

3. Fox News (2016) Victims' families in Texas 'affluenza' case outraged after teen avoids jail again.

4. Jacqueline Lee (2016) Stanford sex assault: Brock Turner gets 6 months in jail.

5. Emanuella Grinberg, Joe Sutton (2016) Ex-University of Colorado student's sex assault sentence questioned.

6. Tarik Minor (2016) Many serve little jail time for having sex with students: I-TEAM exposes stunning double standard for teachers.

7. Mary McMurran (2009) Personality, personality disorder and violence: An Introduction. In: Mary McMurran, Richard Howard (Eds.), Personality, Personality Disorder and Violence, Wiley-Blackwell, UK, p. 3-18.

8. Nestor PG (2002) Mental disorder and violence: personality dimensions and clinical features. Am J Psychiatry 159(12): 1973-1978.

9. Jentsch JD, Taylor JR (1999) Impulsivity resulting from frontostriatal dysfunction in drug abuse: implications for the control of behavior by reward-related stimuli. Psychopharmacology (Berl) 146(4): 373-390.

10. Eric Hollander, Dan J Stein (2006) Clinical manual of impulse-control disorders. Arlington: American Psychiatric Publishing, USA.

11. Howard Rick (2009) The neurobiology of affective dyscontrol: Implications for understanding 'dangerous and severe personality disorder'. In: Howard Rick, McMurran Mary (Eds.), Personality, personality disorder and violence, John Wiley \& Sons Ltd, UK, pp. 157174.

12. Gustafson R (1994) Alcohol and aggression. J Offender Rehabil 21(3/4): 41-80.

13. Kai Pernanen, Marie-Marthe Cousineau, Serge Brochu, Fu Sun (2002) Proportions of crimes associated with alcohol and other drugs in Canada. Canadian Centre on Substance Abuse.

14. Goldman D (2014) Genomics of Impulsivity: Integrating Genes and Neuroscience. Nebr Symp Motiv 61: 129-39.
15. Linnoila M, Virkkunen M, Scheinin M, Nuutila A, Rimon R, et al. (1984) Low cerebrospinal fluid 5-hydroxyindoleacetic acid concentration differentiates impulsive from nonimpulsive violent behavior. Life Sci 33(26): 2609-2614.

16. McCloskey MS, Noblett KL, Deffenbacher JL, Gollan JK, Coccaro EF (2008) Cognitive-behavioral therapy for intermittent explosive disorder: a pilot randomized clinical trial. J Consult Clin Psychol 76(5): 876-886.

17. Dorfman HM, Meyer-Lindenberg A, Buckholtz JW (2014) Neurobiological Mechanisms for Impulsive-Aggression: The Role of MAOA. Curr Top Behav Neurosci 17: 297-313.

18. Pavlov KA, Chistiakov DA, Chekhonin VP (2012) Genetic determinants of aggression and impulsivity in humans. J Appl Genet 53(1): 61-82.

19. Niv S, Tuvblad C, Raine A, Wang P, Baker LA (2012) Heritability and longitudinal stability of impulsivity in adolescence. Behav Genet 42(3): 378-92.

20. Bevilacqua L, Doly S, Kaprio J, Yuan Q Tikkanen R, et al. (2010) A population-specific HTR2B stop codon predisposes to severe impulsivity. Nature 468(7327): 1061-1066.

21. Tikkanen R, Tiihonen J, Rautiainen MR, Paunio T1, Bevilacqua L, et al. (2015) Impulsive alcohol-related risk-behvior and emotional dysregulation among individuals with a serotonin 2B receptor stop codon. Transl Psychiatry 5: e681.

22. Scott A Johnson (2014) Understanding the Role of Alcohol during Rape: The Perfect Storm of Attention, Emotion, \& Expectancies. International Journal of Emergency Mental Health \& Human Resilience 16: 30-39.

23. Scott A Johnson (2009) Masking a Sex Offense: When a Non-Sex Crime Really is a Sex Crime. The Forensic Examiner. 18, 3, 46-50

24. Turchik Jessica A, Probst Danielle R, Irvin Clinton R, Chau Minna, Gidycz Christine A (2010) Prediction of Sexual Assault Experiences in College Women Based on Rape Scripts: A Prospective Analysis. Psychology of Violence 1: 76-83.

25. Patricia Tjaden, Nancy Thoennes (2006) Extent, Nature, and Consequences of Rape Victimization: Findings from the National Violence against Women Survey. Special Report, National Institute of Justice and the Centers for Disease Control and Prevention, USA.

26. Patricia Tjaden, Nancy Thoennes (2000) Full Report of the Prevalence, Incidence, and Consequences of Violence against Women: Findings from the National Violence against Women Survey. Research Report, National Institute of Justice and the Centers for Disease Control and Prevention, USA.

27. Peggy Heil, Sean Ahlmeyer, Dominique Simons (2003) Crossover sexual offenses. Sexual Abuse: A Journal of Research and Treatment 15(4): 221-236.

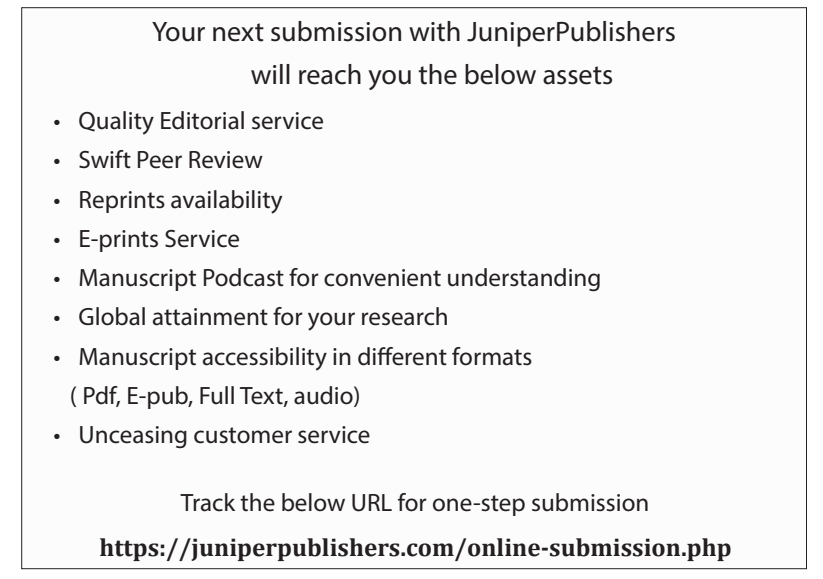

